\title{
Quality of water recovered by treating acid mine drainage using pervious concrete adsorbent
}

\author{
AN Shabalala1,2* and SO Ekolu' \\ 'Department of Civil Engineering Science, University of Johannesburg, PO Box 524, Auckland Park 2006, South Africa \\ ${ }^{2}$ University of Mpumalanga, P/Bag X 11283, Mbombela 1200, South Africa
}

\begin{abstract}
In this paper, a batch experiment was conducted to evaluate the water quality obtained from using pervious concrete (PERVC) technology to treat acid mine drainage (AMD). The study proposes an innovative application of PERVC as a permeable reactive barrier liner in evaporation ponds. The effectiveness of PERVC adsorbent in removing heavy metals was compared with that of zero-valent iron (ZVI) of particle size 1.0 to $1.8 \mathrm{~mm}$. The AMD used in the study was obtained from abandoned gold and coal mines. PERVC mixtures consisted of granite aggregate and ordinary Portland cement CEM I 52.5R (CEM I) or CEM I containing Class F $30 \%$ fly ash $(30 \% \mathrm{FA})$ as a cement replacement material. ZVI was prepared from a mixture of silica sand and iron grit of specific sizes. PERVC and ZVI media were used to conduct batch reactor tests with AMD, for a period of 43 days at a ratio of $1 \mathrm{~L}$ of reactive material to $3 \mathrm{~L}$ of AMD. The quality of treated AMD was compared against effluent discharge standards. The contaminants Al, Fe and Zn were effectively removed by both PERVC and ZVI. Also, both adsorbents reduced $\mathrm{Ni}$, $\mathrm{Co}$ and $\mathrm{Cu}$ to levels below those measured in raw AMD. However, PERVC was more effective in removing $\mathrm{Mn}$ and $\mathrm{Mg}$ while ZVI was ineffective. Although PERVC removed more heavy metals and with greater efficiency than ZVI, the PERVC-treated water showed high $\mathrm{pH}$ levels and exhibited elevated $\mathrm{Cr}^{6+}$ concentrations, owing to leaching from the cement and fly ash materials used in PERVC mixtures.
\end{abstract}

Keywords: Pervious concrete, zero-valent iron, acid mine drainage, batch test, permeable reactive barrier

\section{INTRODUCTION}

Water preservation, recycling and reuse is quickly becoming inevitable as urbanisation and growth of the human population continues to stretch the demands on water availability in various nations. Water in some countries is quite a scarce commodity. Southern Africa is among the known water-stressed regions, amongst others such as the Middle East, China, etc. (Jobson, 1999; Procházka et al., 2018). It is estimated that $40 \%$ of the world population may be living in water-scarce or -stressed countries within the next 50 years (Bichai et al., 2016). A critical strategy for future water security lies in development of a portfolio of supply sources, including water recycling. A common source which is already widely employed in several countries is reuse of treated municipal wastewater. Another potential resource for water recovery is acid mine drainage (AMD).

AMD typically occurs in abandoned mining sites rich in pyrites which are typically found embedded in mineral ore sources. Upon extraction of minerals during a mining activity, the pyrites are left exposed to atmospheric conditions within the mined rock sources or tailings. Under these exposure conditions, pyrites undergo oxidation forming acidic water discharge. Similarly, acid sulphate soils contain sulphidic materials which typically result in acidic water run-off, i.e., AMD (Igarashi and Oyama, 1999; Testa et al., 2013; Komnitsas et al., 1995; Fitzpatrick, 2003). AMD dissolves acid-soluble heavy metals from tailings and deposits the contaminants through a variety of mechanisms, including precipitation and surface sorption onto soils and water courses, endangering the ecological systems, and plant and aquatic life (Fripp et al., 2000).

A simplified Eq. 1 gives the pyritic oxidation reaction leading to AMD formation (Kefeni et al., 2015; Ford, 2003; Akcil

${ }^{*}$ Corresponding author, email: Ayanda.Shabalala@ump.ac.za Received 5 December 2017; accepted in revised form 23 September 2019 and Koldas, 2006; Petrik el al., 2006). The presence of some bacterial species, especially Thiobacillus ferrooxidans, is known to remarkably oxidize iron and sulphur in pyrites, typically at a low $\mathrm{pH}<3.5$ (Igarashi and Oyama, 1999; Testa et al., 2013; Komnitsas et al., 1995; Blowes et al., 2003; Younger, 2004).

$$
2 \mathrm{FeS}_{2}+7.5 \mathrm{O}_{2}+7 \mathrm{H}_{2} \mathrm{O} \rightarrow 2 \mathrm{Fe}(\mathrm{OH})_{3}+4 \mathrm{H}_{2} \mathrm{SO}_{4}
$$

AMD emanates from its source which may be an underground or open-cast mine, then flows to the surrounding environment that may include soil, wetlands, water courses or water bodies. AMD is typically characterised by acidity and high concentrations of heavy metals. As a result of its chemical composition, it tends to be highly aggressive to the natural ecosystem. It pollutes wetlands, lakes, rivers, etc., usually destroying aquatic life and rendering these water resources unsuitable for human or animal consumption and for agricultural uses. Also, AMD contamination strangulates animal and plant life, and renders barren even soils that were naturally fertile (Fripp et al., 2000; Ochieng et al., 2010). The acidic nature of AMD causes corrosion of infrastructure used in dams, bridges, water pumping and supply, amongst others (Gitari et al., 2008; Pagnanelli et al., 2009; Offeddu et al., 2015; Macías et al., 2012a). Figure 1 shows an AMD source in a South African open-cast mine. Crystallised metal and/ or sulphate mineral salts can be seen deposited at the soil surface, following evaporation of AMD-contaminated seepage water in the soils (Antivachis et al., 2016; Harris et al., 2003). The dam in Fig. 1 may also be considered as an evaporation pond, which serves as the AMD receptor prior to effluent discharge into the river downstream.

\section{Sustainable treatment of acid mine drainage}

Active treatment of AMD, by dosing with lime or other chemicals, is presently the most commonly used technique. 


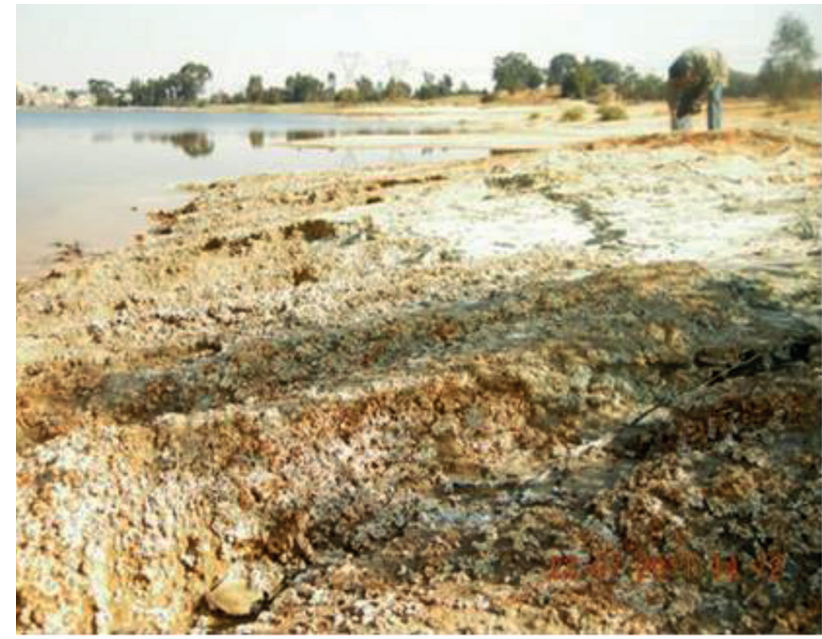

Figure 1. A dam of acid mine drainage emanating from surrounding mining activity in South Africa, showing crystallization of heavy metal salts on soils rendering it non-life supporting $(\mathrm{pH}=2.7, \mathrm{EC}=$ $340 \mathrm{mS} / \mathrm{m}$ )

However, this method has major disadvantages, including the formation of sludge which itself has to be disposed of, the high cost of chemicals, labour and equipment maintenance (Hengen et al., 2014). These treatment costs can be so high as to be non-sustainable in the long-term, as commonly seen in some developing countries.

Passive treatment systems, such as the wetland system and permeable reactive barriers (PRBs), are considered to be among the most sustainable options as they do not require continuous chemical inputs, nor do they involve high maintenance. PRBs have emerged as one of the most promising passive systems for treatment of contaminated groundwater (Phillips, 2009; Thiruvenkatachari et al., 2008; Amos and Younger, 2003; Komnitsas et al., 2006). It is a cost-effective technology that could be used to treat groundwater with an underground $\mathrm{PRB}$ or to treat surface water with a PRB liner in facultative evaporation ponds. The latter innovation is the preoccupation of the present paper. A typical PRB consists of a trench or wall filled with granular material which is sufficiently permeable to allow passage of groundwater through it, as determined by the natural groundwater flow regime.

Various types of reactive materials have been studied for potential use in PRBs. The most common of them is zero-valent iron (ZVI) as indicated by various studies (Cundy et al., 2008; Suponik and Blanco, 2014; Moraci and Calabró, 2010; Gusmão et al., 2004; Cantrell et al., 1995; Komnitsas et al., 2006). Others, including activated carbon, zeolites, peat, sawdust, oxygen-releasing compounds, etc., have also been used and evaluated (Thiruvenkatachari et al., 2008; Obiri-Nyarko et al., 2014). Alkaline materials such as limestone, hydrated or slaked lime and dolomite are commonly used to treat groundwater that is contaminated by AMD. These materials have been shown to effectively remove divalent and trivalent metal cations such as copper, cadmium, lead and zinc from solution (Wang et al., 2016; Gitari et al., 2008; Pagnanelli et al., 2009; Offeddu et al., 2015; Macías et al., 2012a).

Several recent pioneering studies (Shabalala et al., 2017; Solpuker et al., 2014; Ekolu et al., 2016a; Shabalala, 2013) have shown pervious concrete (PERVC) technology to be an effective system for polluted water remediation. Ekolu and Bitandi (2018) showed PERVC to also possess greater treatment longevity, of about twice that of ZVI. PERVC is a mixture of single size coarse aggregate, Portland cement, water, and little to no sand. It is typically used to drain stormwater run-off from the streets, parking lots, driveways, and walkways. Porous pavements are known to reduce surface run-off and to minimize stormwater accumulation during a rain event in urbanised areas. Studies show that PERVC can also function as a pollution sink for runoff, owing to its particle retention capacity through filtration (Ekolu et al., 2014a and Solpuker et al., 2014). The high porosity of PERVC leads to good water infiltration and air exchange rates (Scholz and Grabowiecki, 2007).

\section{Objectives}

It has been shown that ordinary evaporation ponds hardly improve the quality of contaminated mine water (Mapanda et al., 2007). However, they provide effective interception points that can be exploited to employ AMD treatment, for example, by introducing alkaline materials and sulphate-reducing bacteria (SRB) using limestone, manure, etc. (Barnhisel et al., 2000; Macías et al., 2012b; Metesh et al., 1998).

This paper proposes an innovative application of PERVC as a PRB liner in evaporation ponds, for recovery of water from AMD. To the best knowledge of the authors, the proposed use is the first of such PERVC application. Accordingly, a batch reactor experiment was conducted to evaluate the water quality obtained by using PERVC made using Portland cement of grade CEM I 52.5R (CEM I) or CEM I/FA mixture containing $30 \% \mathrm{FA}(30 \% \mathrm{FA})$ as a cement replacement material. Comparisons were then made on treatability of AMD using PERVC versus using ZVI as adsorbents. The measurements conducted on water include physico-chemical parameters, changes in water quality due to the various treatments, adsorption parameters, and removal efficiency. The quality of treated water was evaluated against the United States Environmental Protection Act (USEPA, 1986) and South Africa's National Water Act (RSA, 1999) being the standards for effluent disposal to the environment.

\section{EXPERIMENTAL STUDY}

\section{Configuration}

The experiment comprised batch tests conducted on AMD using PERVC and ZVI adsorbents. The batch reactor set-up depicts a configuration of PERVC-PRB liner in a facultative evaporation pond or dam, as illustrated in Fig. 2a. Often, these ponds are trapezoidal or rectangular-shaped, claylined trenches that serve as receptors of contaminated mine water seepage. From these ponds, the effluent may be discharged into the adjacent natural water body or stream. The present study proposes to provide a PERVC-PRB liner upon the walls of evaporation ponds. AMD undergoes treatment as it passes through the PERVC-PRB lining. As shown in previous studies (Ekolu et al., 2016a), PERVC is highly porous and has high hydraulic conductivity that allows uninhibited flow of water through its pore network, as also depicted in Fig. 2b (Yang and Jiang, 2003). As water percolates through the pore network of the PERVC liner, it comes in contact with highly alkaline cement paste in the concrete matrix. This paste neutralises the AMD by raising its $\mathrm{pH}$, in turn leading to precipitation of dissolved heavy metals from the polluted mine-water (Shabalala et al., 2017; Ekolu and Bitandi, 2018). 
(a) Pervious concrete PRB lining

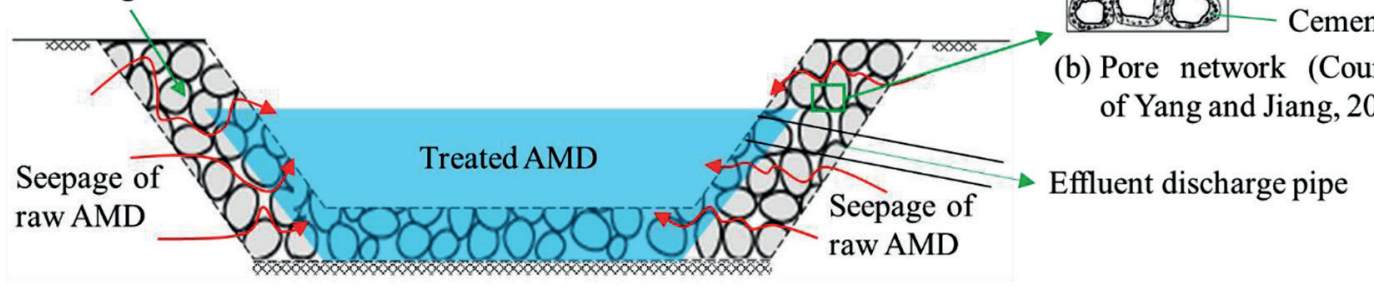

Figure 2. Pervious concrete reactive barrier lining in evaporation ponds of acid mine drainage

\section{Acid mine drainage and reactive media}

The AMD types used in the study were obtained from abandoned gold and coal mines, anonymously designated as WZ and TDB, respectively. AMD was collected from field sources using high density polyethylene containers and transported to the laboratory for use in the experiments. As already mentioned, the reactive media comprising PERVC and ZVI were used. PERVC was made using constituents consisting of Portland cement CEM I 52.5R with or without 30\% fly ash (FA), and $6.7 \mathrm{~mm}$ granite aggregate. In an earlier study (Ekolu et al., 2014b), it was shown that FA rapidly neutralises AMD, attaining maximum $\mathrm{pH}$ within 10 to $15 \mathrm{~min}$.

The chemical compositions of the cementitious materials used are given in an associated paper (Shabalala et al., 2017) and repeated in Table 1 for convenience. Evidently, the FA used was of Class F category (ASTM C 618, 2015). The granite aggregate used was selected following an earlier study, which involved aggregates of different types and sizes (Ekolu et al., 2016a).

Also given in Shabalala et al. (2017) are mixture details, including the mix design, mixing and casting procedures for the $100 \mathrm{~mm}$ PERVC cubes used. The mixes were designated as CEM1 for the PERVC made of ordinary Portland cement, and 30\%FA for PERVC containing 30\% FA as a partial cement replacement material. Incorporation of $30 \%$ FA into the concrete mixture provides effective resistance to potential acid attack by AMD (Ekolu et al., 2016b; Shabalala et al., 2017).

The composition of $\mathrm{ZVI}$ was $80.6 \% \mathrm{Fe}_{2} \mathrm{O}_{3}, 0.72 \% \mathrm{MnO}$, $0.24 \% \mathrm{Al}_{2} \mathrm{O}_{3}, 0.19 \% \mathrm{Cr}_{2} \mathrm{O}_{3}, 0.03 \% \mathrm{MgO}, 0.02 \% \mathrm{ZnO}$ and trace elements. Evidently, the ZVI had a high iron content. The density of ZVI is $7800 \mathrm{~kg} / \mathrm{m}^{3}$, while its specific surface area is typically 1.0 to $2.0 \mathrm{~m}^{2} / \mathrm{g}$. In PERVC, the hardened cement paste (HCP) forms a coating on aggregate particles and reacts with AMD (Fig. 2). The density of HCP is $1900-1950 \mathrm{~kg} / \mathrm{m}^{2}$ and its Brunauer-Emmet-Teller (BET) specific surface area is 30 to $100 \mathrm{~m}^{2} / \mathrm{g}$ (Hunt, 1966; Thomas et al., 1998; Ekolu and Bitandi, 2018).

Commercially available ZVI material supplied by B.V. Boksburg (Pty) Ltd, was used in the study. In preparing the ZVI-sand mixture, standard $100 \mathrm{~mm}$ cube moulds were filled with equal proportions of fine silica sand of size range 0.4 to $0.85 \mathrm{~mm}$, coarse silica sand of size range 0.8 to $1.8 \mathrm{~mm}$, fine ZVI grade GH 80 of size range 0.18 to $0.42 \mathrm{~mm}$ and coarse
ZVI grade GH 18 of size range 1.0 to $1.4 \mathrm{~mm}$. The fine particles of ZVI result in low porosity and low permeability, making it vulnerable to fast clogging. By incorporating sand into ZVI, the mixture attains increased porosity and higher permeability for better hydraulic conductivity and reduced clogging (Bartzas and Komnitsas, 2010).

\section{Batch reactor experiment}

In the batch reactor set-up, $1 \mathrm{~L}$ cube of CEM $1,1 \mathrm{~L}$ cube of $30 \% \mathrm{FA}$ and $-1 \mathrm{~L}$ of ZVI-sand mixture, were each placed in a $4 \mathrm{~L}$ plastic container; $3 \mathrm{~L}$ of WZ or TDB were added to each container. Table 2 gives the quantities of constituents used in the batch set-up. Vadapalli et al. (2008) observed that active treatment and neutralization of AMD to circumneutral or alkaline $\mathrm{pH}$ was optimized when the ratio of AMD to reactive media was maintained at 3:1 by volume. Accordingly, a ratio of $1 \mathrm{~L}$ of reactive material to $3 \mathrm{~L}$ of AMD was used in the present study. Containers were tightly closed to ensure no evaporation took place. During the first 10 days, aqueous samples of 200 $\mathrm{mL}$ were collected once a day and stored at room temperature. Thereafter, the sampling frequency was decreased to once a week. The experiment was conducted continuously for a period of 43 days.

\section{Measurements and analyses}

Measurement of $\mathrm{pH}$ was conducted using the MP-103 microprocessor-based $\mathrm{pH} / \mathrm{mV} /$ Temp tester. $\mathrm{pH}$ tests were done immediately upon collection of aqueous samples from batch tests. The $\mathrm{pH}$ electrode was calibrated using standard NIST traceable $\mathrm{pH}$ 2.0, 4.0, 7.0 and 10.0 buffers. Samples of treated

Table 2. Adsorbent mixtures used in the batch experiment

\begin{tabular}{llc}
\hline Adsorbents & Solid constituents & $\begin{array}{c}\text { Acid mine } \\
\text { drainage } \\
(\mathbf{m L})\end{array}$ \\
\hline CEM I & One 100 mm cube, 1 L & 3000 \\
$30 \% F A$ & One $100 \mathrm{~mm}$ cube, 1 L & 3000 \\
ZVI & Iron grit and sand mixture*, 1 L & 3000 \\
\hline
\end{tabular}

${ }^{*}$ Comprised $25 \%$ iron grit GH18, 25\% iron grit GH80, 25\% silica sand of $0.4-0.85 \mathrm{~mm}$ size, $25 \%$ silica sand of $0.8-1.8 \mathrm{~mm}$ size

Table 1. Chemical compositions of Portland cement and fly ash (Shabalala et al., 2017)

\begin{tabular}{lcccccccccccc}
\hline & $\mathrm{SiO}_{2}$ & $\mathrm{Al}_{2} \mathrm{O}_{3}$ & $\mathrm{CaO}$ & $\mathrm{Fe}_{2} \mathrm{O}_{3}$ & $\mathrm{MgO}$ & $\mathrm{TiO}_{2}$ & $\mathrm{Mn}_{2} \mathrm{O}_{3}$ & $\mathrm{Na}_{2} \mathrm{O}_{3}$ & $\mathrm{~K}_{2} \mathrm{O}$ & $\mathrm{P}_{2} \mathrm{O} 5$ & $\mathrm{LOI}$ \\
\hline CEM I 52.5R (\%) & 21.90 & 4.75 & 65.44 & 3.68 & 2.17 & 0.49 & 0.40 & 0.17 & 0.25 & 0.06 & 1.57 \\
Fly ash (\%) & 50.32 & 24.57 & 7.31 & 5.91 & 1.83 & 1.53 & 0.05 & 0.16 & 0.76 & 0.47 & 5.59 \\
\hline
\end{tabular}


AMD were collected into $220 \mathrm{~mL}$ plastic vials, stored at $4^{\circ} \mathrm{C}$ and analysed for $\mathrm{Al}, \mathrm{Fe}, \mathrm{Zn}, \mathrm{Mn}, \mathrm{Na}, \mathrm{Mg}, \mathrm{K}, \mathrm{Ca}, \mathrm{Mn}, \mathrm{Fe}, \mathrm{Co}, \mathrm{Ni}$ and $\mathrm{Cu}$. The Perkin Elmer SCIEX (Concord, Ontario, Canada) ELAN 6000 inductively coupled plasma mass spectrometer (Perkin Elmer, 2003) was employed for the water analyses. $\mathrm{SO}_{4}$ concentration was determined using ion chromatography, Dionex QIC-IC.

Adsorption capabilities of the reactive media were assessed based on retention parameters consisting of the amount of metal adsorbed $\left(q_{e}\right)$ in $\mathrm{mg} / \mathrm{g}$, contaminant removal efficiency (RE\%), partition (also referred to as adsorption or distribution) coefficient $\left(K_{d}\right)$ in $\mathrm{mL} / \mathrm{g}$. Eqs. 2 to 4 give the expressions used to calculate these parameters. +-

$$
\begin{aligned}
& q_{e}(\mathrm{mg} / \mathrm{g})=\left(C_{o}-C_{e}\right) \frac{V}{m} \\
& \operatorname{RE}(\%)=\frac{C_{o}-C_{e}}{C_{o}} \times 100 \\
& K_{d}=\left[\frac{C_{o}-C_{e}}{C_{e}}\right] \frac{V}{m}
\end{aligned}
$$

where $C_{\mathrm{o}}$ is the initial concentration of the contaminant in AMD $(\mathrm{mg} / \mathrm{L}),{ }_{e} C_{e}$ is equilibrium concentration of the contaminant $(\mathrm{mg} / \mathrm{L}), V$ is volume $(\mathrm{L}), m$ is mass of the reactive material or adsorbent $(\mathrm{g})$.

\section{RESULTS AND DISCUSSION}

The subsequent sections give the results obtained upon AMD treatment using PERVC and ZVI. The two AMD types used in the present study had different elemental compositions and acidity levels with $\mathrm{pH}$ values of 4.15 and 5.79 for WZ and TDB, respectively. Chemical analyses of WZ samples showed high metal concentrations of $\mathrm{Ca}(582 \mathrm{mg} / \mathrm{L}), \mathrm{Mg}(170 \mathrm{mg} / \mathrm{L}), \mathrm{Na}(139 \mathrm{mg} / \mathrm{L})$, $\mathrm{Mn}(131 \mathrm{mg} / \mathrm{L}), \mathrm{Fe}(12 \mathrm{mg} / \mathrm{L})$ and $\mathrm{Al}(3 \mathrm{mg} / \mathrm{L})$, while TDB also had high contents of $\mathrm{Ca}(470 \mathrm{mg} / \mathrm{L}), \mathrm{Mg}(214 \mathrm{mg} / \mathrm{L}), \mathrm{Na}(3061$ $\mathrm{mg} / \mathrm{L}), \mathrm{Fe}(9 \mathrm{mg} / \mathrm{L})$ and $\mathrm{Al}(6 \mathrm{mg} / \mathrm{L})$. Both, the WZ and TDB had high $\mathrm{SO}_{4}$ concentrations of 1123 and $2870 \mathrm{mg} / \mathrm{L}$, respectively.

Figures 3 to 9 show the $\mathrm{pH}$ results and the changes in concentrations of heavy metals, with duration of the treatment. These results are discussed comparing the treatability of AMD using PERVC relative to using ZVI.

\section{pH change}

During the batch reactor experiments, the $\mathrm{pH}$ values of raw AMD increased from 4.15 or 5.79 before treatment to $\mathrm{pH}=6$

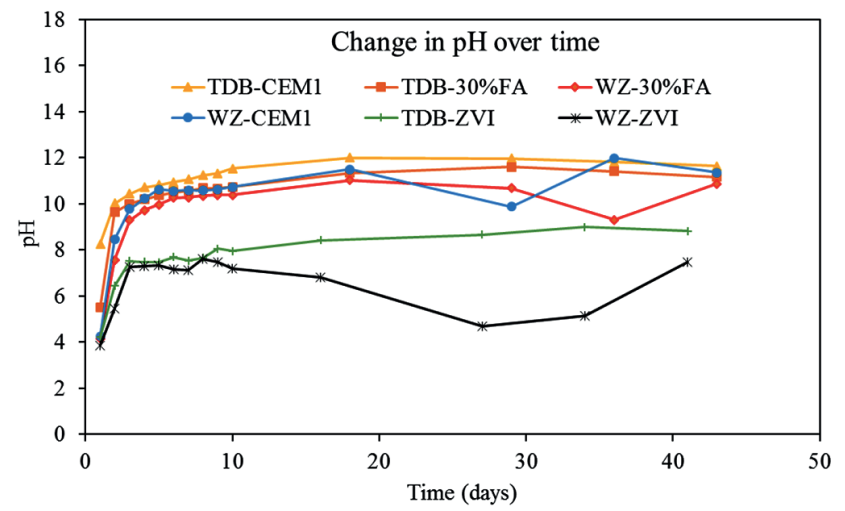

Figure 3. Changes in $\mathrm{pH}$ values of acid mine drainage during treatment to 8 for ZVI and $\mathrm{pH}=9$ to 12 for PERVC after treatment, as seen in Fig. 3. For both reactive media, a rapid increase of $\mathrm{pH}$ was observed within the first 24 hours of the experiment. For a given reactive material, the treated TDB always gave $\mathrm{pH}$ levels that were 1 to 2 points higher than the corresponding values for WZ. The high $\mathrm{pH}$ values observed in PERVC-treated AMD are related to dissolution of portlandite from the cementitious matrix, which adds alkalinity to the system (Chandrappa and Biligiri, 2016). In the experiments conducted using ZVI, the oxidation of ZVI to ferrous and ferric iron caused the increase in $\mathrm{pH}$. As already indicated, lower final $\mathrm{pH}$ values were attained for acidic AMD water samples that were treated using ZVI as compared to those that were treated using PERVC.

\section{Effect of using plain pervious concrete}

Figure 4 presents the changes in concentrations of $\mathrm{Al}, \mathrm{Fe}$ and Mn during 43 days of the batch tests. The neutralising capacity of PERVC is attributed to the large quantity of portlandite phase which adds alkalinity to the solution. CEM I effectively removed $\mathrm{Al}, \mathrm{Fe}, \mathrm{Zn}$ and $\mathrm{Mn}$ from both $\mathrm{WZ}$ and TDB with efficiency levels of $98 \%$ to $100 \%$. In all the treated AMD samples, i.e., WZ-CEM1, TDB-CEM1, WZ-30\%FA, TDB-30\%FA, WZ-ZVI and TDB-ZVI, there was generally no consistent decrease in the concentration of sulphate, as seen in Fig. 5. It can be concluded that none of the reactive media were successful in removing sulphate. While most metals precipitate out of solution at high $\mathrm{pH}$, sulphate remains in solution and does not precipitate since its stability is not $\mathrm{pH}$ dependent. However, some sulphate may be removed by
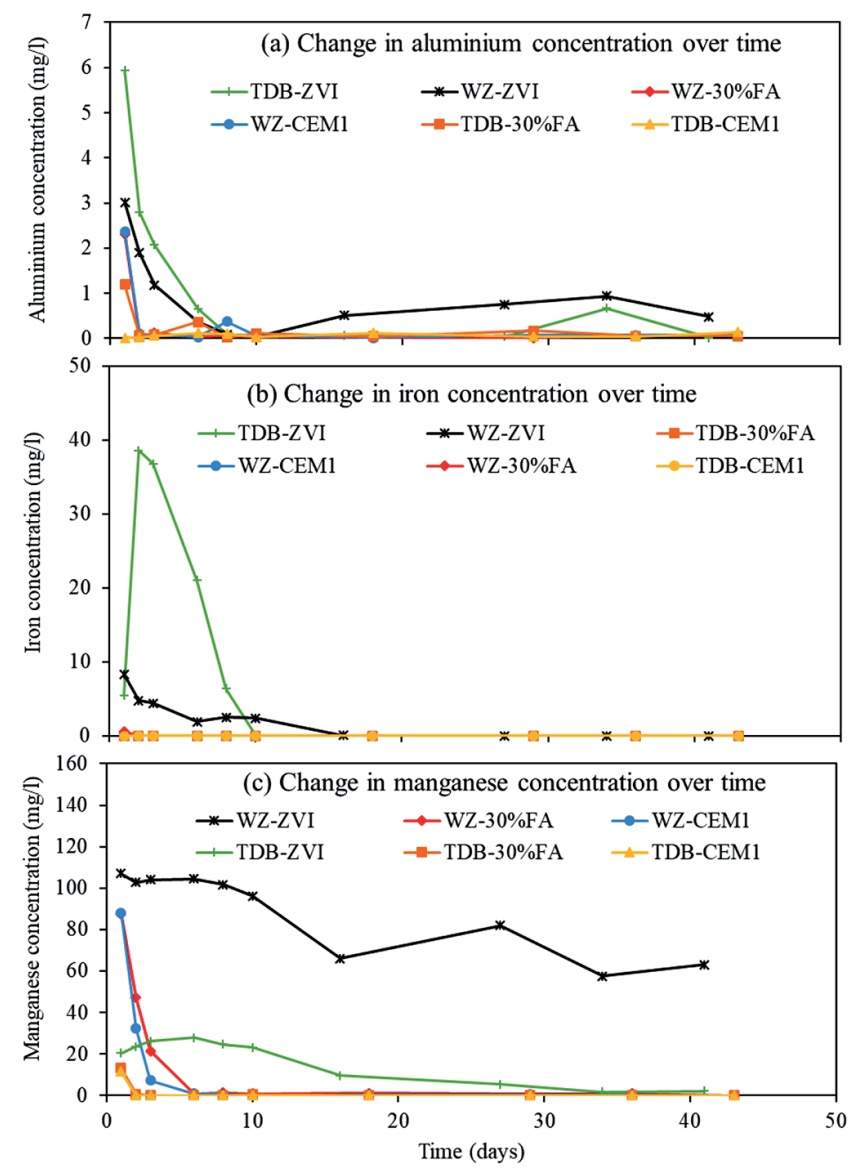

Figure 4. Changes in (a) aluminium, (b) iron and (c) manganese concentrations 


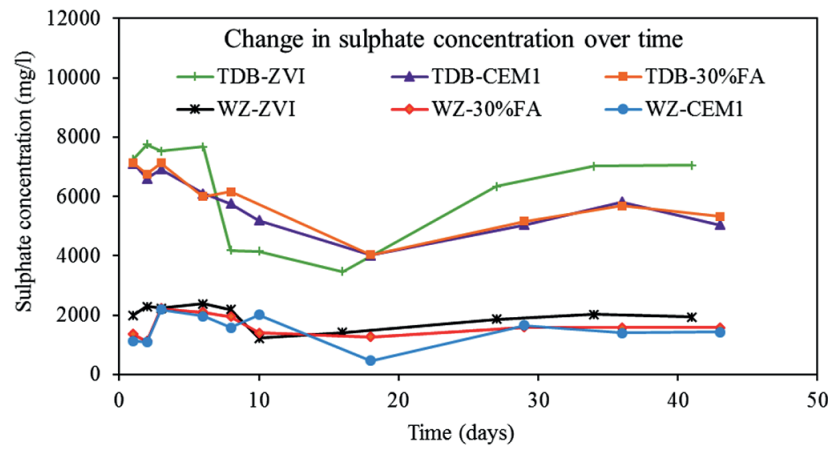

Figure 5. Changes in sulphate concentrations

PERVC as gypsum precipitate (Shabalala et al., 2017). Treatment methods such as microbial remediation of AMD using SRB, filtration, electrocoagulation, adsorption and ion exchange are considered as promising alternatives for sulphate removal (Fernando et al., 2018).

It can be seen in Figs 6 and 7 that the concentrations of $\mathrm{Pb}, \mathrm{Zn}, \mathrm{Ni}$, Co and $\mathrm{Cu}$ decreased as the $\mathrm{pH}$ of the solution increased. Precipitation of metal hydroxides and oxides may explain the observed reductions in concentrations of these contaminants (Aube, 2004; Seneviratne, 2007). The $\mathrm{Ni}, \mathrm{Cu}, \mathrm{Pb}$ and $\mathrm{Zn}$ metals may have precipitated as $\mathrm{Ni}(\mathrm{OH})_{2}, \mathrm{Cu}(\mathrm{OH})_{2}$, $\mathrm{Pb}(\mathrm{OH})_{2}$ and $\mathrm{Zn}(\mathrm{OH})_{2}$, respectively. The removal of cobalt is probably due to its adsorption onto, or co-precipitation with, iron and aluminium hydroxides or hydrosulphates. At $\mathrm{pH}$ values between 8 and $9, \mathrm{Ni}$ is adsorbed onto calcite in solution (Kefeni et al., 2015).

\section{Effect of using pervious concrete mixtures containing fly ash}

Major reductions in concentrations of most metals were observed for WZ-30\%FA and TDB-30\%FA as shown in Figs 4, 6 and 7. The $30 \% \mathrm{FA}$ adsorbent removed $99 \%$ of Al, reducing it from $3 \mathrm{mg} / \mathrm{L}$ in raw WZ to $0.07 \mathrm{mg} / \mathrm{L}$ in WZ-30\%FA, and from $6 \mathrm{mg} / \mathrm{L}$ in raw TDB to $0.05 \mathrm{mg} / \mathrm{L}$ in TDB-30\%FA (Fig. $4 \mathrm{a}$ ). The observed reductions of $\mathrm{Al}$ concentration in WZ-30\%FA and in TDB-30\%FA may have resulted through the formation of amorphous $\mathrm{Al}(\mathrm{OH})_{3}$ (Komnitsas et al., 2004). As $\mathrm{pH}$ increases, $\mathrm{Fe}^{3+}$ precipitates to form amorphous ferric hydroxides and oxyhydroxides, which explains the complete removal of iron from $\mathrm{WZ}-30 \% \mathrm{FA}$ and TDB-30\%FA.

The concentrations of $\mathrm{Pb}, \mathrm{Zn}, \mathrm{Ni}, \mathrm{Co}$ and $\mathrm{Cu}$ in raw $\mathrm{AMD}$ were generally low and decreased to undetectable levels after PERVC or ZVI treatment. Removal of Ni can be attributed to its precipitation as $\mathrm{Ni}(\mathrm{OH})_{2}$ and possible adsorption on the precipitating amorphous $\mathrm{Al}$ and $\mathrm{Fe}$-oxyhydroxides. $\mathrm{Cu}$ tends to precipitate as cupric and cuprous fernite and may be adsorbed onto the surface of FA at $\mathrm{pH}$ values between 5 and 6 . $\mathrm{Zn}$ co-precipitates with $\mathrm{Si}$ that is solubilised from FA and forms willemite (Vadapalli et al., 2008).

\section{Effect of using zero-valent iron}

When raw AMD was treated using ZVI, the concentrations of most metals measured in the batch tests decreased, as seen in Figs. 4, 6 and 7. Al removal levels were $82 \%$ and $97 \%$ for WZ-ZVI and TDB-ZVI, respectively. In Fig. 4c, the reduction of $\mathrm{Mn}$ concentration from $107 \mathrm{mg} / \mathrm{L}$ in raw WZ to $63 \mathrm{mg} / \mathrm{L}$ in

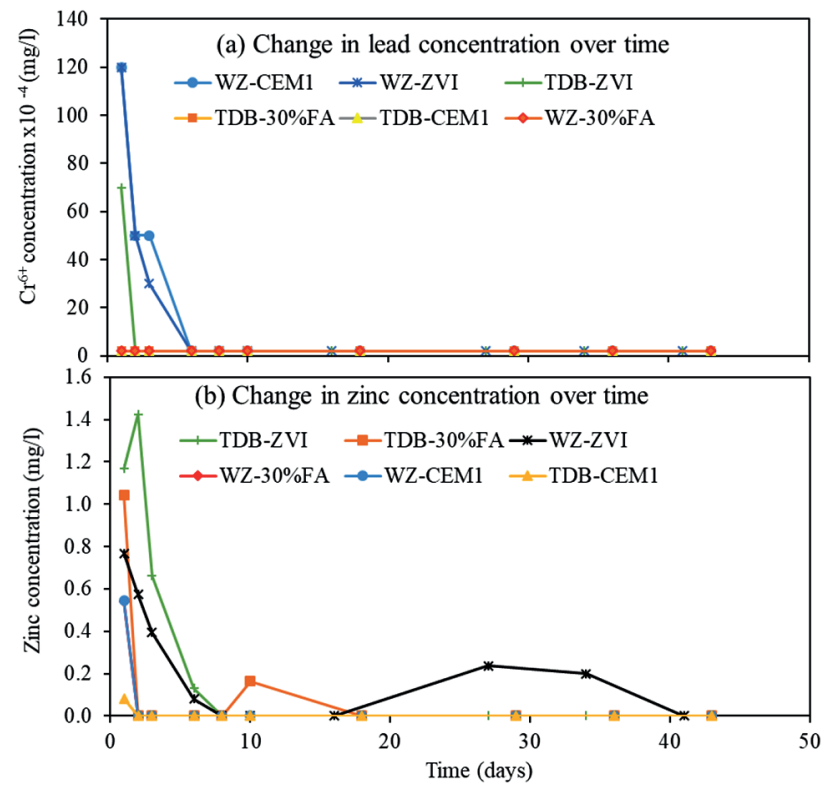

Figure 6. Changes in (a) lead and (b) zinc concentrations
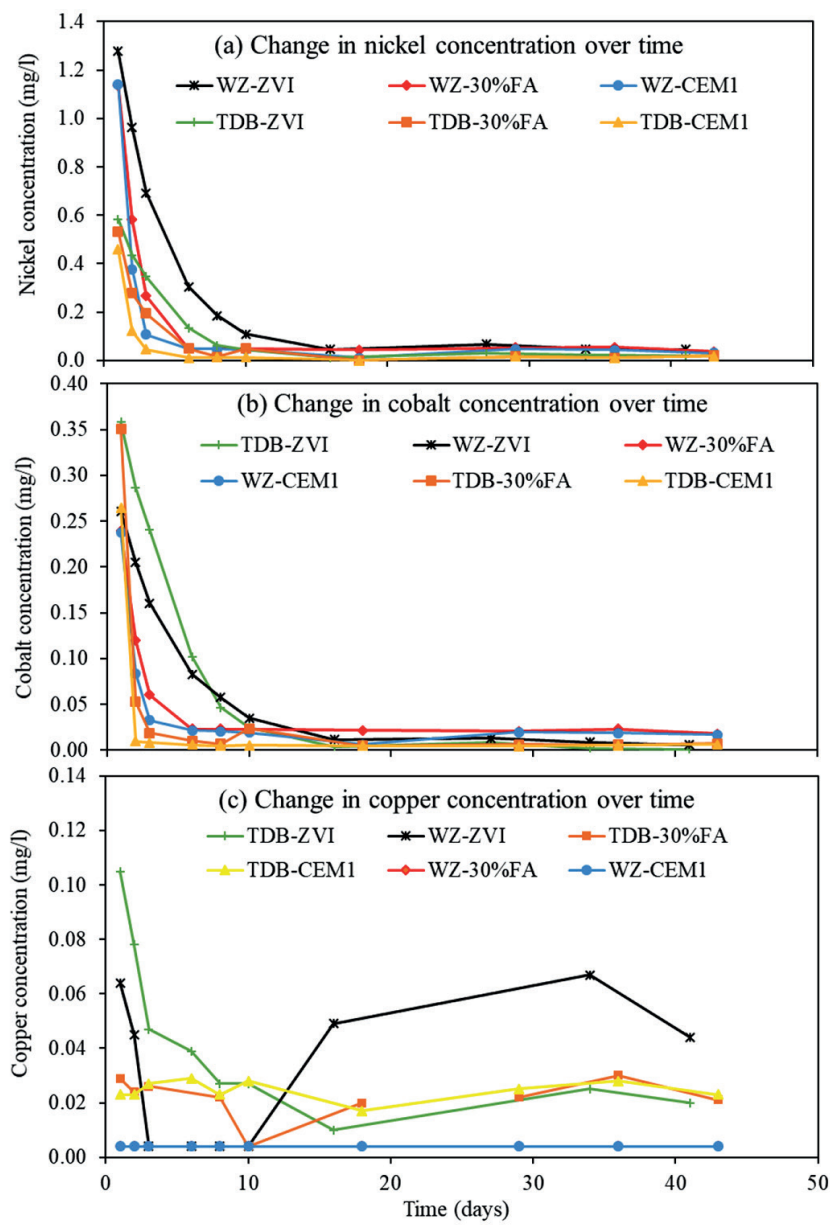

Figure 7. Changes in (a) nickel, (b) cobalt and (c) copper concentrations

WZ-ZVI, and from $20 \mathrm{mg} / \mathrm{L}$ in raw TDB to $2 \mathrm{mg} / \mathrm{L}$ in TDB$\mathrm{ZVI}$, may be attributed to its precipitation as $\mathrm{Mn}(\mathrm{OH})_{2}$ at alkaline or neutral $\mathrm{pH}$. 
Concentrations of $\mathrm{Pb}, \mathrm{Zn}, \mathrm{Ni}$, Co and $\mathrm{Cu}$ were maintained at low values following ZVI treatment, as seen in Figs. 6 and 7. When $\mathrm{Fe}^{0}$ is oxidised to $\mathrm{Fe}^{2+}$ then to $\mathrm{Fe}^{3+}$, various iron corrosion products $\mathrm{Fe}(\mathrm{OH})_{2}, \mathrm{FeOOH}, \mathrm{Fe}(\mathrm{OH})_{3}$ may form (Schwertmann and Murad, 1983), as shown in Eqs 5 to 7

$$
\begin{aligned}
& \mathrm{Fe}^{3+}+2 \mathrm{H}_{2} \mathrm{O} \rightarrow \mathrm{FeOOH}+3 \mathrm{H}^{+} \\
& 2 \mathrm{Fe}^{2+}+3 \mathrm{H}_{2} \mathrm{O} \rightarrow \mathrm{Fe}_{2} \mathrm{O}_{3}+6 \mathrm{H}^{+} \\
& 3 \mathrm{Fe}^{2+}+4 \mathrm{H}_{2} \mathrm{O} \rightarrow \mathrm{Fe}_{3} \mathrm{O}_{4}+8 \mathrm{H}^{+}
\end{aligned}
$$

Metals in cationic forms may be sorbed onto these iron corrosion products (Lindsay et al., 2008; Hashim et al., 2011; Bartzas and Komnitsas, 2010). Thus, it is likely that the main processes for $\mathrm{Ni}$ (II), Co (II), Cu (II) and Zn (II) removal are their adsorption onto the surface of iron corrosion products. $\mathrm{Ni}, \mathrm{Co}$ and $\mathrm{Zn}$ may also be precipitated as metal hydroxides.

\section{Alkali metal changes for treatments done using pervious concrete and ZVI adsorbents}

Figure 8a shows that the $\mathrm{K}$ concentration levels remained elevated in both the PERVC (CEM I, 30\%FA)-treated and the ZVI-treated AMD water. Also, there were no significant reductions in $\mathrm{Ca}$ and $\mathrm{Mg}$ concentrations of the ZVI-treated AMD, as seen in Figs. 8b and 8c. Interestingly, high removal of $\mathrm{Mg}$ was achieved in AMD samples that were treated using PERVC but the ZVI-treated samples showed very low $\mathrm{Mg}$ removal. The PERVC's Mg removal levels for WZ and TDB were, respectively, $96 \%$ and $99 \%$, while ZVI gave corresponding removal levels of $12 \%$ and $16 \%$. Mg removal by PERVC was observed to be optimal at a $\mathrm{pH}$ range of 9 to 11 and may be attributed to the formation of brucite and hydrotalcite in solution (Solpuker et al., 2014).

\section{Removal efficiencies}

The metal removal efficiency levels were calculated as summarised in Table 3. Average equilibrium concentrations of each contaminant over the period 10 to 43 days were calculated and used to determine its proportional decrease or increase relative to its initial level in raw $\mathrm{AMD}$. $\mathrm{Al}, \mathrm{Fe}, \mathrm{Zn}$ and $\mathrm{Pb}$ had zero or undetectable concentrations after treatment with CEM I or 30\%FA. For the purpose of conducting calculations, the equilibrium concentrations of these contaminants were assumed to be $0.01 \mathrm{mg} / \mathrm{L}$.

As seen in Table 3, the $\mathrm{Al}, \mathrm{Fe}, \mathrm{Ni}, \mathrm{Co}, \mathrm{Pb}$ and $\mathrm{Zn}$ were successfully removed by all the reactive media (CEM 1 , $30 \% \mathrm{FA}, \mathrm{ZVI}$ ), with removal efficiency levels of up to $100 \%$. The removal efficiency levels for $\mathrm{Al}, \mathrm{Mn}, \mathrm{Mg}$ and $\mathrm{Cu}$ were greater
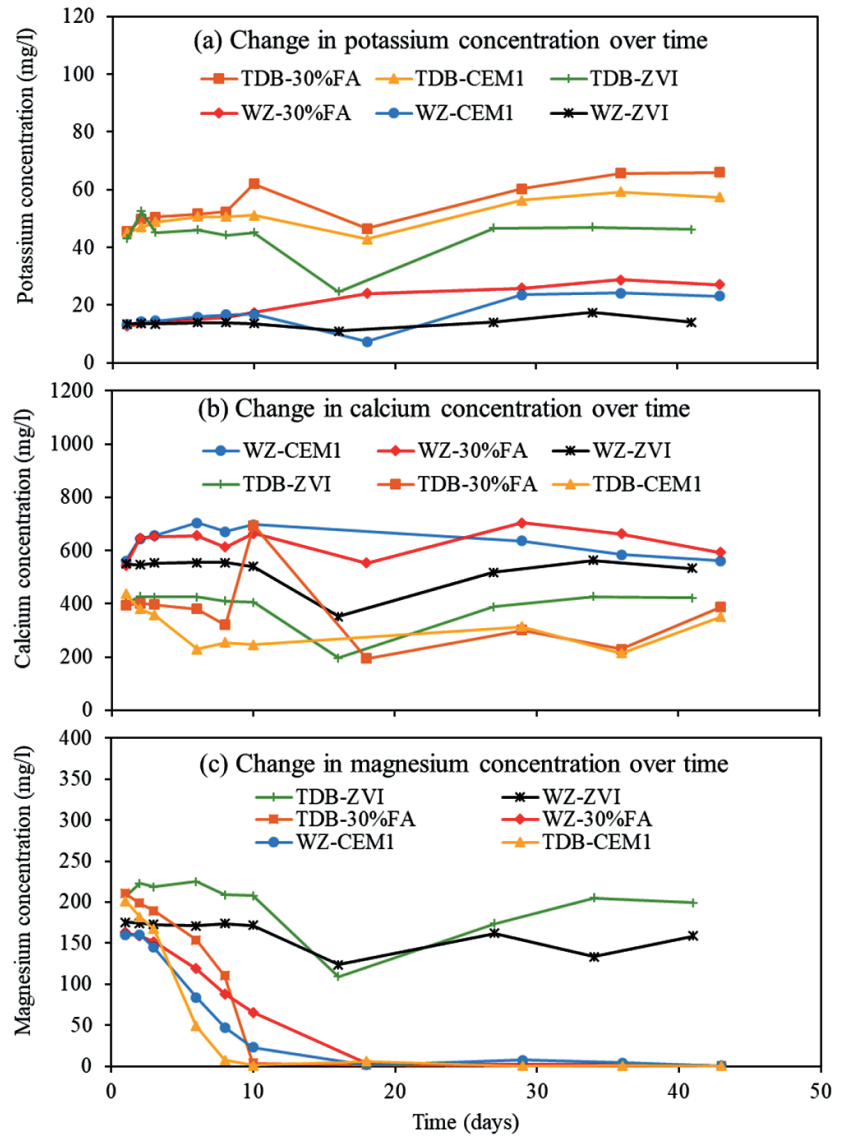

Figure 8. Behaviour of alkalis showing changes in (a) potassium, (b) calcium and (c) magnesium concentrations

when AMD was treated using CEM I or 30\%FA relative to the treatment with ZVI. For instance, $91 \%$ to $100 \%$ of $\mathrm{Mn}$ and $\mathrm{Mg}$ in $\mathrm{WZ}$ or TDB were removed by CEM I or $30 \% \mathrm{FA}$, yet ZVI treatment correspondingly achieved a low $44 \%$ to $58 \%$ removal of $\mathrm{Mn}$ and even lower $12 \%$ to $16 \%$ removal of $\mathrm{Mg}$. Clearly, the ZVI adsorbent was ineffective while PERVC was very effective in removing both $\mathrm{Mn}$ and $\mathrm{Mg}$ from raw AMD.

A comparison is given in Fig. 9 showing the equilibrium concentrations of the major contaminants in AMD before and after treatment. It is clear from Fig. 9(a) that the major heavy metals present in AMD were completely removed or reduced to negligible concentrations when treated using CEM I or $30 \% \mathrm{FA}$. The contaminants removed by CEM I or $30 \% \mathrm{FA}$ include $\mathrm{Mn}$ and $\mathrm{Mg}$. The ZVI also removed most heavy metals except $\mathrm{Mg}$ and $\mathrm{Mn}$. The inability of ZVI to remove these two contaminants is attributed to the lower $\mathrm{pH}$, of 6 to 8 , attainable

\begin{tabular}{|c|c|c|c|c|c|c|c|c|c|c|c|}
\hline $\begin{array}{l}\text { AMD } \\
\text { Type }\end{array}$ & Adsorbent & $\begin{array}{c}\mathrm{Al} \\
(\%)\end{array}$ & $\begin{array}{c}\mathrm{Fe} \\
(\%)\end{array}$ & $\begin{array}{l}\text { Mn } \\
(\%)\end{array}$ & $\begin{array}{l}\mathrm{SO}_{4} \\
(\%)\end{array}$ & $\begin{array}{l}\text { Mg } \\
(\%)\end{array}$ & $\begin{array}{c}\mathrm{Ni} \\
(\%)\end{array}$ & $\begin{array}{l}\text { Co } \\
(\%)\end{array}$ & $\begin{array}{l}\mathrm{Cu} \\
(\%)\end{array}$ & $\begin{array}{l}\mathrm{Pb} \\
(\%)\end{array}$ & $\begin{array}{l}\mathrm{Zn} \\
(\%)\end{array}$ \\
\hline \multirow[t]{3}{*}{ WZ } & CEM1 & 98 & 100 & 100 & -24 & 96 & 97 & 93 & 99 & 99 & 99 \\
\hline & $30 \% \mathrm{FA}$ & 99 & 100 & 99 & -32 & 91 & 96 & 93 & 99 & 99 & 99 \\
\hline & ZVI & 82 & 96 & 44 & -51 & 12 & 95 & 97 & 70 & 99 & 94 \\
\hline \multirow[t]{3}{*}{ TDB } & CEM1 & 99 & 100 & 100 & -75 & 99 & 98 & 98 & 80 & 99 & 100 \\
\hline & $30 \% \mathrm{FA}$ & 99 & 100 & 99 & -46 & 99 & 97 & 98 & 80 & 99 & 99 \\
\hline & ZVI & 97 & 100 & 58 & -95 & 16 & 95 & 98 & 80 & 99 & 100 \\
\hline
\end{tabular}
through ZVI treatment, while CEM I or $30 \% \mathrm{FA}$ attained a $\mathrm{pH}$

Table 3. Contaminant removal efficiency levels achieved using pervious concrete and ZVI reactive media 
of 9 to 11, which is the range for precipitation of $\mathrm{Mn}$ and $\mathrm{Mg}$. Since sulphate removal is not $\mathrm{pH}$ dependent, none of the media effectively removed or reduced $\mathrm{SO}_{4}$ concentrations. It is notable in Fig. $9 \mathrm{~b}$ that the concentration of $\mathrm{SO}_{4}$ increased
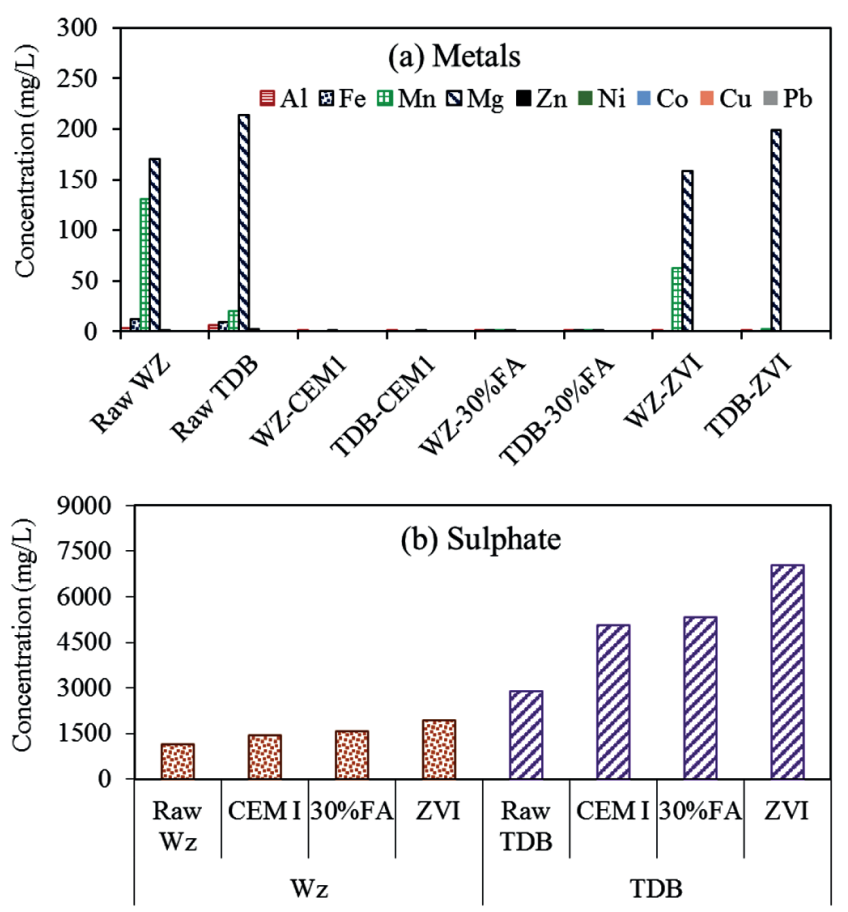

Figure 9. Concentrations of contaminants in acid mine drainage after 43 days of batch reactor treatment using pervious concrete or ZVI (a) heavy metals, (b) sulphates

Table 4. Retention of heavy metals by the various reactive media

\begin{tabular}{lccrrr}
\hline & & \multicolumn{2}{c}{ WZ } & \multicolumn{2}{c}{ TDB } \\
\cline { 3 - 6 } & & $q_{e}(\mathrm{mg} / \mathrm{g})$ & $K_{d}(\mathrm{~mL} / \mathrm{g})$ & $q_{e}(\mathrm{mg} / \mathrm{g})$ & $K_{d}(\mathrm{~mL} / \mathrm{g})$ \\
\hline CEM I & $\mathrm{Al}$ & 1.72 & 28.73 & 3.47 & 43.39 \\
& $\mathrm{Fe}$ & 7.03 & 703.02 & 5.02 & 501.81 \\
& $\mathrm{Zn}$ & 0.82 & 0.08 & 1.64 & 163.59 \\
& $\mathrm{Mn}$ & 76.62 & 232.17 & 11.72 & 585.75 \\
& $\mathrm{Mg}$ & 95.49 & 13.35 & 124.63 & 85.95 \\
& $\mathrm{Ni}$ & 0.74 & 18.47 & 0.35 & 34.59 \\
& $\mathrm{Co}$ & 0.16 & 8.21 & 0.23 & 22.87 \\
& $\mathrm{Cu}$ & 0.06 & 58.05 & 0.05 & 2.35 \\
\hline $30 \% \mathrm{FA}$ & $\mathrm{Al}$ & 1.52 & 38.00 & 3.04 & 38.00 \\
& $\mathrm{Fe}$ & 6.16 & 615.66 & 5.02 & 501.81 \\
& $\mathrm{Zn}$ & 0.71 & 71.37 & 1.42 & 47.41 \\
& $\mathrm{Mn}$ & 66.92 & 0.10 & 10.21 & 85.07 \\
& $\mathrm{Mg}$ & 79.78 & 5.45 & 109.31 & 98.48 \\
& $\mathrm{Ni}$ & 0.64 & 12.84 & 0.30 & 14.89 \\
& $\mathrm{Co}$ & 0.14 & 7.19 & 0.20 & 20.03 \\
& $\mathrm{Cu}$ & 0.05 & 50.83 & 0.04 & 2.05 \\
\hline ZVI & $\mathrm{Al}$ & 1.37 & 2.49 & 3.26 & 20.37 \\
& $\mathrm{Fe}$ & 6.42 & 13.11 & 5.02 & 501.81 \\
& $\mathrm{Zn}$ & 0.73 & 8.12 & 1.56 & 155.74 \\
& $\mathrm{Mn}$ & 32.41 & 0.44 & 6.49 & 0.78 \\
$\mathrm{Mg}$ & 11.23 & 0.07 & 19.55 & 0.11 \\
& $\mathrm{Ni}$ & 0.69 & 11.54 & 0.32 & 10.61 \\
& $\mathrm{Co}$ & 0.16 & 16.19 & 0.22 & 21.77 \\
& $\mathrm{Cu}$ & 0.04 & 1.30 & 0.04 & 2.23 \\
\hline
\end{tabular}

following AMD treatment using each of the adsorbents. The $\mathrm{ZVI}$ treatment gave greater increase in the $\mathrm{SO}_{4}$ concentrations compared to CEM I and 30\%FA treatments, while the latter showed a slightly higher $\mathrm{SO}_{4}$ increase than the former.

\section{Retention properties of reactive media}

Results showing the retention characteristics of CEM I, 30\%FA and ZVI are given in Table 4 for the various heavy metals. For each type of AMD, the uptake of heavy metals $\left(q_{e}\right)$ was similar for both PERVC media i.e. CEM I and 30\%FA. It can also be observed that ZVI had a similar metal uptake as PERVC, except for the metals Mn and Mg where the uptake by ZVI was quite low. For WZ, the uptake of $\mathrm{Mn}$ or $\mathrm{Mg}$ by PERVC was in the range 67 to $95 \mathrm{mg} / \mathrm{g}$ which is much higher than the 11 to $32 \mathrm{mg} / \mathrm{g}$ uptake by ZVI. Similarly for TDB, the $\mathrm{Mn}$ or Mg uptake of 11 to $125 \mathrm{mg} / \mathrm{g}$ by PERVC is much higher compared with 6 to $20 \mathrm{mg} / \mathrm{g}$ uptake by ZVI. These results are consistent with the inability of ZVI to significantly remove $\mathrm{Mn}$ and $\mathrm{Mg}$, while PERVC adsorbents were effective in removing these contaminants, as discussed earlier. PERVC adsorbents also showed higher uptake of metals from TDB relative to their corresponding uptake from WZ. These observations underscore the relative ease of metal release by TDB as opposed to $\mathrm{WZ}$ which appears to be more difficult to treat.

The adsorption coefficient $K_{d}$ gives the proportion of metal concentration sorbed by the reactive media relative to the concentration left dissolved in solution, as expressed in Eq. 4. CEM I and 30\%FA were generally more effective sorbents compared to ZVI. For instance, ZVI showed little to no sorption of $\mathrm{Mn}$ and $\mathrm{Mg}$ giving $K_{d}=0.11$ to $0.78 \mathrm{~mL} / \mathrm{g}$ in TDB, compared to the corresponding 85 to $586 \mathrm{~mL} / \mathrm{g}$ for PERVC. It is, however, notable that sorption of $\mathrm{Mn}$ by $30 \% \mathrm{FA}$ was quite diminished in WZ unlike in TDB where higher sorption was observed. However, sorption of Mn in WZ by CEM I was also high. This observation may be related to the dilution effect of using FA as a partial replacement material in Portland cement.

\section{Evaluation of treated water quality}

The contaminant concentrations in AMD before and after treatment with CEM I, 30\%FA and ZVI were compared with the limits specified in USEPA (1986) and RSA (1999) standards for pollutant discharge to the environment. Table 5 gives comparisons for the various contaminants in the raw AMD, treated WZ, and treated TDB. It may be noted that the standard limits given in USEPA (1986) and RSA (1999) are the requirements for discharge of pollutants to a water resource.

As shown in the table, both the raw WZ and raw TDB fail, for almost all the contaminants, to meet the standard requirements for pollutant discharge into a water resource. Treatment of both AMD types using ZVI reduces the concentration levels of contaminants to limits generally meeting the USEPA (1986) and NWA (1999) criteria for discharge of treated AMD to the environment, with the exception of $\mathrm{Mn}$. Treatment of AMD using CEM I or 30\%FA leads to lower heavy metal concentrations relative to using ZVI; however, the PERVC-treated AMD water exhibits undesirably high $\mathrm{pH}$ levels and elevated $\mathrm{Cr}^{6+}$ concentrations (Table 5). It is known that both acidity and high alkalinity of water inhibit microbial growth. A circumneutral $\mathrm{pH}$ range, typically 6.5 to 7.5 , is essential for sustenance of microbial activity and the ecosystem, generally.

$\mathrm{Cr}^{6+}$ is known to be carcinogenic (Zhitkovich, 2011; WHO, 2003). Both CEM I and 30\%FA materials do release $\mathrm{Cr}^{6+}$ into 
treated water, leading to concentration elevation beyond the maximum limits of 0.10 and $0.05 \mathrm{mg} / \mathrm{L}$ specified in USEPA (1986) and NWA (1999), respectively.

Also, all the reactive media resulted in elevation of $\mathrm{SO}_{4}$ concentration in the treated AMD, but there is no specified $\mathrm{SO}_{4}$ limit given in USEPA (1986) and NWA (1999) for pollutant discharge to water bodies. The concentrations of most contaminants in CEM I-treated or 30\%FA-treated water also meet the specified limits for drinking water standards (SANS 241: SABS, 2015), except for $\mathrm{Na}, \mathrm{SO}_{4}, \mathrm{Cr}^{6+}$ and the high $\mathrm{pH}$ of 11. The ZVI-treated AMD water also fails to meet the drinking water limits for $\mathrm{Na}, \mathrm{SO}_{4}, \mathrm{Mg}$ and $\mathrm{Mn}$ (Table 5).

\section{CONCLUSIONS}

In this study, the resulting water quality obtained from treating acid mine drainage using pervious concrete or zero-valent iron was compared against water standards for discharge of effluents to the environment. Based on findings from the investigation, the following conclusions are drawn:

(a) In both of the AMD treatments done using pervious concrete and zero-valent iron, a rapid increase in $\mathrm{pH}$ was observed during the first $24 \mathrm{~h}$ of the experiment. For pervious concrete treatment, a maximum $\mathrm{pH}$ of 9 to 12 was attained as compared to 6 to 8 obtained after treatment of acid mine drainage using zero-valent iron.

(b) The removal efficiency levels for $\mathrm{Al}, \mathrm{Fe}, \mathrm{Zn}, \mathrm{Mn}, \mathrm{Mg}$, Ca, and $\mathrm{Cu}$ were 93 to $100 \%$ when acid mine drainage was treated using pervious concrete as compared to the corresponding 12 to $99 \%$ for the treatment done using zero-valent iron. $\mathrm{Mn}, \mathrm{Mg}$ and $\mathrm{Cu}$ exhibited the lowest removal levels, of $44,12,70 \%$, respectively, obtained upon treatment of acid mine drainage using zerovalent iron. After treatment of acid mine drainage using pervious concrete or zero-valent iron, the equilibrium concentration of $\mathrm{SO}_{4}$ was always higher than that in raw acid mine drainage. For both the pervious concrete and zero-valent iron adsorbents, the $\mathrm{Ni}, \mathrm{Co}$ and $\mathrm{Cu}$ in the treated mine drainage were maintained at levels below those in raw acid mine drainage.

(c) The main process responsible for heavy metal removal when raw acid mine drainage was treated using zero-valent iron is the adsorption of precipitates onto the surface of iron corrosion products. However, the removal mechanism associated with the use of pervious concrete to treat acid mine drainage is not fully understood; further research is needed.

(d) Pervious concrete mixtures were found to be better sorbents than zero-valent iron, as indicated by comparison of metal uptake and adsorption coefficients for the different contaminants.

(e) Acid mine drainage treatment using zero-valent iron produces water that generally meets the standard criteria for pollutant disposal to the environment. Treatment of acid mine drainage using pervious concrete containing cement with or without fly ash, gave better water quality than the treatment done using zero-valent iron. However, the AMD water that was treated using pervious concrete failed to meet the limits applicable for discharge of effluent into a water resource, mainly due to the resulting elevated $\mathrm{Cr}^{6+}$ and high $\mathrm{pH}$ levels of the treated water. These issues need to be resolved to allow potential practical use of pervious concrete in water treatment applications. Further investigations are ongoing to improve the pervious concrete treatment system.

Table 5. Comparison of treated water quality against pollutant discharge standards

\begin{tabular}{|c|c|c|c|c|c|c|c|c|c|c|c|}
\hline & \multirow{2}{*}{$\begin{array}{c}\text { Raw } \\
\text { WZ } \\
(\mathrm{mg} / \mathrm{L})\end{array}$} & \multirow{2}{*}{$\begin{array}{c}\text { Raw } \\
\text { TDB } \\
\text { (mg/L) }\end{array}$} & \multirow{2}{*}{$\begin{array}{c}\text { EPA* }^{*} \\
\text { effluent } \\
\text { discharge } \\
\text { standards } \\
\text { (mg/L) }\end{array}$} & \multirow{2}{*}{$\begin{array}{l}\text { NWA }^{* *} \\
\text { waste } \\
\text { discharge } \\
\text { limits } \\
\text { (mg/L) }\end{array}$} & \multirow{2}{*}{$\begin{array}{c}\text { SANS } 241 \\
\text { drinking } \\
\text { water } \\
\text { limits } \\
\text { (mg/L) }\end{array}$} & \multicolumn{3}{|c|}{ WZ treated using } & \multicolumn{3}{|c|}{ TDB treated using } \\
\hline & & & & & & $\begin{array}{c}\mathrm{ZVI} \\
(\mathrm{mg} / \mathrm{L})\end{array}$ & $\begin{array}{l}\text { CEM I } \\
(\mathrm{mg} / \mathrm{L})\end{array}$ & $\begin{array}{l}30 \% \text { FA } \\
\text { (mg/L) }\end{array}$ & $\begin{array}{c}\mathrm{ZVI} \\
(\mathrm{mg} / \mathrm{L})\end{array}$ & $\begin{array}{l}\text { CEM I } \\
(\mathrm{mg} / \mathrm{L})\end{array}$ & $\begin{array}{l}30 \% \mathrm{FA} \\
(\mathrm{mg} / \mathrm{L})\end{array}$ \\
\hline $\mathrm{pH}$ & 4.15 & 5.79 & $5.5-9.0$ & $5.5-9.5$ & $5.0-9.7$ & 7.5 & 11.4 & 10.9 & 8.8 & 11.6 & 11.2 \\
\hline $\mathrm{Ca}$ & 582 & 470 & & & & 533.9 & 560.5 & 593.5 & 422.4 & 350.6 & 387.36 \\
\hline$M g$ & 170 & 214 & & & & 158.7 & 0.08 & 0.49 & 199.3 & 0.08 & 0.11 \\
\hline $\mathrm{Na}$ & 139 & 3061 & & & $\leq 200$ & 120 & 139 & 132 & 2879 & 2694 & 2793 \\
\hline K & 15 & 47 & & & & 14.02 & 23.06 & 27.04 & 46.23 & 57.4 & 65.9 \\
\hline $\mathrm{SO}_{4}^{2-}$ & 1123 & 2870 & & & $\leq 500$ & 1932.4 & 1427.5 & 1571.8 & 7045 & 5045.1 & 5319.65 \\
\hline $\mathrm{Fe}^{4}$ & 12 & 9 & $\leq 3.0$ & $\leq 0.3$ & $\leq 2$ & 0 & 0 & 0 & 0 & 0 & 0 \\
\hline $\mathrm{Al}$ & 3 & 6 & & $\leq 0.03$ & $\leq 0.3$ & 0.49 & 0.08 & 0.07 & 0.02 & 0.14 & 0.05 \\
\hline $\mathrm{Mn}$ & 131 & 20 & $\leq 2.0$ & & $\leq 0.4$ & 63.02 & 0 & 0.07 & 2.03 & 0.01 & 0.01 \\
\hline $\mathrm{Zn}$ & 1.4 & 2.8 & $\leq 5.0$ & $\leq 0.1$ & $\leq 5$ & 0 & 0 & 0 & 0 & 0 & 0 \\
\hline $\mathrm{Cu}$ & 0.1 & 0.1 & $\leq 3.0$ & $\leq 0.01$ & $\leq 2$ & 0.044 & 0.004 & 0.004 & 0.020 & 0.023 & 0.021 \\
\hline Co & 0.3 & 0.4 & & & $\leq 0.5$ & 0.006 & 0.017 & 0.018 & 0.001 & 0.006 & 0.007 \\
\hline $\mathrm{Ni}$ & 1.3 & 0.6 & $\leq 3.0$ & & & 0.05 & 0.03 & 0.04 & 0.02 & 0.02 & 0.02 \\
\hline $\mathrm{Cr}$ & 0.067 & 0.068 & $\leq 2.0$ & & $\leq 0.07$ & 0.006 & 0.511 & 0.719 & 0.008 & 2.65 & 0.655 \\
\hline $\mathrm{Cr}^{6+}$ & 0.012 & 0.016 & $\leq 0.1$ & $\leq 0.05$ & $\leq 0.05$ & 0.0008 & 0.436 & 0.706 & 0.0008 & 2.04 & 0.503 \\
\hline B & $<0.2$ & 1.04 & & $\leq 1.0$ & $\leq 2.4$ & 0.157 & 0.067 & 0.184 & 0.597 & 0.388 & 0.632 \\
\hline $\mathrm{Pb}$ & $<0.03$ & $<0.03$ & $\leq 0.1$ & $\leq 0.01$ & $\leq 0.01$ & $\mathrm{Nd}$ & nd & 0.0002 & nd & nd & 0.0002 \\
\hline
\end{tabular}

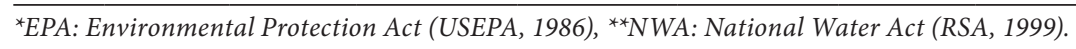




\section{ACKNOWLEDGEMENTS}

This paper is based on acid mine drainage research project at the University of Johannesburg, partly funded by the National Research Foundation (NRF) of South Africa, IPRR Grant No. 96800 and the University of Mpumalanga (UMP). The authors are grateful for the financial support given.

\section{REFERENCES}

AKCIL A and KOLDAS S (2006) Acid mine drainage (AMD): causes, treatment and case studies. J. Clean Prod. 14 (12-13) 1139-1145. https://doi.org/10.1016/j.jclepro.2004.09.006

AMOS PW and YOUNGER PL (2003) Characterisation for a subsurface reactive barrier to treat colliery spoil leachate. Water Res. 37 (1) 108-120. https://doi.org/10.1016/s0043-1354(02)00159-8 ANTIVACHIS DN, CHATZITHEODORIDIS E, SKARPELIS N and KOMNITSAS K (2016) Secondary sulphate minerals in a cyprustype ore deposit, Apliki, Cyprus: Mineralogy and its implications regarding the chemistry of pit lake waters. Mine Water Environ. 36 (2) 226-238. https://doi.org/10.1007/s10230-016-0398-0

ASTM C 618-15 (2015) Standard specification for coal fly ash and raw or calcined natural pozzolan for use in concrete. ASTM international, West Conshohocken.

AUBE B (2004) The science of treating acid mine drainage and smelter effluents, 361 Aumais, Ste-Anne-de-Bellevue, Quebec, Canada, 23p. URL: www.enviraube.com (Accessed 18 June 2017).

BARNHISEL RI, DARMODY RG, DANIELS WL, SKOUSEN J, SEXSTONE A and ZIEMKIEWICZ P (2000) Acid mine drainage control and treatment. Chapter 6 in: Reclamation of Drastically Disturbed Lands. Agronomy Monograph No. 41. American Society of Agronomy and American Society for Surface Mining and Reclamation, Madison WI. https://doi.org/10.2134/agronmonogr41.c6

BARTZAS G and KOMNITSAS K (2010) Solid phase studies and geochemical modelling of low-cost permeable reactive barriers. J. Hazardous Mater. 183 (1-3) 301-308. https://doi.org/10.1016/j. jhazmat.2010.07.024

BICHAI F, GRINDLE AK and MURTHY SL (2018) Addressing barriers in the water-recycling innovation system to reach water security in arid countries. J. Clean Prod. 171 (Supplement) S97S109. https://doi.org/10.1016/j.jclepro.2016.07.062

BLOWES DW, PTACEK CJ, JAMBOR JL and WEISENER CG (2003) The geochemistry of acid mine drainage. University of Waterloo, Canada. 196 pp.

CANTRELL KJ, KAPLAN DI and WIETSMA TW (1995) Zerovalent iron for the in situ remediation of selected metals in groundwater. J. Hazardous Mater. 42 (2) 201-212. https://doi. org/10.1016/0304-3894(95)00016-n

CHANDRAPPA AK and BILIGIRI KP (2016) Pervious concrete as a sustainable pavement material - research findings and future prospects: A state-of-the-art review. Constr. Build. Mater. 111 262-274. https://doi.org/10.1016/j.conbuildmat.2016.02.054

CUNDY AB, HOPKINSON L and WHITBY RLD (2008) Use of iron-based technologies in contaminated land and groundwater remediation: A review. Sci. Total Environ. 400 42-51.

EKOLU SO and BITANDI LK (2018) Prediction of longevities of ZVI and pervious concrete reactive barriers using the transport simulation model. J. Environ. Eng. 144 (9) https://doi.org/10.1061/ (ASCE)EE.1943-7870.0001402.

EKOLU SO, AZENE FZ and DIOP S (2014a) A concrete reactive barrier for acid mine drainage treatment. Water Manage. 167 (7) 373-380. https://doi.org/10.1680/wama.13.00035

EKOLU SO, DIOP S and AZENE F (2014b) Bottom ash and fly ash wastes as alkalinising reagents for acid mine drainage. Proceedings of the International Conference on Construction Materials and Structures (ICCMATS), 24-26 November 2014, Johannesburg, South Africa. 1427-1435.

EKOLU SO, DIOP S and AZENE F (2016a) Properties of pervious concrete for hydrological applications. Concrete Beton 144 18-25.

EKOLU SO, DIOP S, AZENE F and MKHIZE N (2016b) Disintegration of concrete construction induced by acid mine drainage attack. J. S. Afr. Inst. Civ. Eng. 58 (1) 34-42. http://dx.doi. org/10.17159/2309-8775/2016/v58n1a4

FERNANDO WAM, ILANKOON IMSK, SYED TH and YELLISHETTY M (2018) Challenges and opportunities in the removal of sulphate ions in contaminated mine water: A review. Miner. Eng. 117 74-90. https://doi.org/10.1016/j.mineng.2017.12.004

FITZPATRICK RW (2003) Overview of acid sulfate soil properties, environmental hazards, risk mapping and policy development in Australia. In: Roach IC (ed.) Advances in Regolith. RC LEME, Adelaide. 22-125.

FORD KL (2003) Passive treatment systems for acid mine drainage. Technical Note 409, Bureau of Land Management Web based report, Colorado. URL: www.blm.gov/nstc/library/pdf/TN409.PDF (Accessed 10 September 2017).

FRIPP J, SIENKIEWICZ PF and CHAKRAVORKI H (2000) Acid mine drainage treatment. EMRRP Technical Notes Collection (ERDC TN-EMRRPSR-14). U.S. Army Engineer Research and Development Center, Vicksburg.

GUSMÃO AD, DE CAMPOS T, NOBRE M and VARGAS E (2004) Laboratory tests for reactive barrier design. J. Hazardous Mater. 110 (1-3) 105-112. https://doi.org/10.1016/j.jhazmat.2004.02.043

HARRIS DL, LOTTERMOSER BG and DUCHESNE J (2003) Ephemeral acid mine drainage at the Montalbion silver mine, north Queensland. Aust. J. Earth Sci. 50 (5) 797-809. https://doi. org/10.1111/j.1440-0952.2003.01029.x

HASHIM MA, MUKHOPADHYAY S, SAHU JN and SENGUPTA B (2011) Remediation technologies for heavy metal contaminated groundwater. J. Environ. Manage. 92 (10) 2355-2388. https://doi. org/10.1016/j.jenvman.2011.06.009

HENGEN TJ, SQUILLACE MK, O'SULLIVAN AD and STONE JJ (2014) Life cycle assessment analysis of active and passive acid mine drainage treatment technologies. Resour. Conserv. Recycl. 86160 167. https://doi.org/10.1016/j.resconrec.2014.01.003

HUNT CM (1966) Nitrogen sorption measurements and surface areas of hardened cement paste. In: Symposium on Structure of Portland Cement Paste and Concrete, Highway Research Board Special Report 90. Highway Research Board, Washington, DC. 11 pp.

IGARASHI T and OYAMA T (1999) Deterioration of water quality in a reservoir receiving pyrite-bearing rock drainage and its geochemical modelling. Eng. Geol. 55 (1-2) 45-55. https://doi. org/10.1016/s0013-7952(99)00105-2

JOBSON S (1999) Water Stressed Regions: The Middle East \& Southern Africa - Global Solutions. University of London, London.

KEFENI KK, MSAGATI TM, MAREE JP and MAMBA BB (2015) Metals and sulphate removal from acid mine drainage in two steps via ferrite sludge and barium sulphate formation. Miner. Eng. 81 79-87. https://doi.org/10.1016/j.mineng.2015.07.016

KOMNITSAS K, XENIDIS A and ADAM K (1995) Oxidation of pyrite and arsenopyrite in sulphidic spoils in Lavrion. Miner. Eng. 8 (12) 1443-1454. https://doi.org/10.1016/0892-6875(95)00109-3

KOMNITSAS K, BARTZAS G and PASPALIARIS I (2004) Efficiency of limestone and red mud barriers: laboratory column studies. Miner. Eng. 17 (2) 183-194. https://doi.org/10.1016/j.mineng.2003.11.006

KOMNITSAS K, BARTZAS G and PASPALIARIS I (2006) Modeling of reaction front progress in fly ash permeable reactive barriers. Environ. Forensics 7 (3) 219-231. https://doi. org/10.1080/15275920600840552

LINDSAY MBJ, PTACEK CJ, BLOWES DW and GOULD WD (2008) Zero-valent iron and organic carbon mixtures for remediation of acid mine drainage: Batch experiments. Appl. Geochem. 23 (8) 2214- 2225. https://doi.org/10.1016/j.apgeochem.2008.03.005

MACÍAS F, CARABALLO MA and NIETO JM (2012a) Environmental assessment and management of metal-rich wastes generated in acid mine drainage passive remediation systems. J. Hazardous Mater 229-230 107-114. https://doi.org/10.1016/j.jhazmat.2012.05.080.

MACÍAS F, CARABALLO MA, NIETO JM, RÖTTING TS and AYORA C (2012b) Natural pre-treatment and passive remediation of highly polluted acid mine drainage. J. Environ. Manage. 104 93-100. https://doi.org/10.1016/j.jenvman.2012.03.027

MAPANDA F, NYAMADZAWO G, NYAMANGARA J and WUTA M (2007) Effects of discharging acid-mine drainage into evaporation 
ponds lined with clay on chemical quality of the surrounding soil and water. Phys. Chem. Earth 32 (15-18) 1366-1375. https://doi. org/10.1016/j.pce.2007.07.041

METESH JJ, JARRELL T and ORAVETZ S (1998) Treating acid mine drainage from abandoned mines in remote areas. Tech. Rep. 9871 2821-MTDC. USDA Forest Service Technology and Development Program. USDA, Missoula, Montana.

MORACI N and CALABRÓ PS (2010) Heavy metal removal and hydraulic performances in zero-valent iron/pumice permeable reactive barriers. J. Environ. Manage. 91 (11) 2336-2341. https://doi. org/10.1016/j.jenvman.2010.06.019

RSA (Republic of South Africa) (1999) Discharge limits and conditions set out in the National Water Act. Government Gazette No. 20526, 8 October 1999. Government Printer, Pretoria.

OBIRI-NYARKO F, GRAJALES-MESA SJ and MALINA G (2014) An overview of permeable reactive barriers for in-situ sustainable groundwater remediation. Chemosphere 111 243-259. https://doi. org/10.1016/j.chemosphere.2014.03.112

OCHIENG GM, SEANEGO ES and NKWONTA OI (2010) Impacts of mining on water resources in South Africa: A review. Sci. Res. Essays 5 (22) 3351-3357.

OFFEDDU FG, CAMA J, SOLER JM, DÁVILA G, MCDOWELL A, CRACIUNESCU T and TISEANU I (2015) Processes affecting the efficiency of limestone in passive treatments for AMD: Column experiments. J. Environ. Chem. Eng. 3 (1) 304-216. https://doi. org/10.1016/j.jece.2014.10.013

PAGNANELLI F, VIGGI CC, MAINELLI S and TORO L (2009) Assessment of solid reactive mixtures for the development of biological permeable reactive barriers. J. Hazardous Mater. 170 (2-3) 998-1005. https://doi.org/10.1016/j.jhazmat.2009.05.081

PERKIN ELMER (2003) ELAN version 3.0 software guide: Simplify ultra-trace analysis. Perkin Elmer, Ontario.

PETRIK L, BURGERS C, GITARI W, SURRENDER D, REYNOLDS K, ELLENDT A, ETCYHEBERS O, VADAPHALLI VRK, KEY D and IWUOHA E (2006) Stability and neutralisation capacity of potential mine backfilling material formed by neutralisation of fly ash and acid mine drainage. WRC Report No. 1458/1/06. Water Research Commission, Pretoria.

PHILLIPS DH (2009) Permeable reactive barriers: A sustainable technology for cleaning contaminated groundwater in developing countries. Desalination 248 (1-3) 352-359. https://doi.org/10.1016/j. desal.2008.05.075

PROCHÁZKA P, HÖNIG V, MAITAH M, PLJUČARSKÁ I and KLEINDIENST J (2018) Evaluation of water scarcity in selected countries of the Middle East. Water 10 (10) 1482 . https://doi. org/10.3390/w10101482

SABS (South African Bureau of Standards) (2015) SANS 241. South African National Standard -Drinking Water. SABS, Pretoria.

SCHOLZ M and GRABOWIECKI P (2007) Review of permeable pavement systems. Build. Environ. 42 (11) 3830-3836. https://doi. org/10.1016/j.buildenv.2006.11.016

SCHWERTMANN U and MURAD E (1983) Effect of pH on the formation of goethite and hematite from ferrihydrate. Clays Clay Miner. 31 (4) 277-284. https://doi.org/10.1346/ccmn.1983.0310405 SENEVIRATNE M (2007) A practical approach to water conservation for commercial and industrial facilities. Queensland Water Commission. Elsevier Ltd, Marrickville. 372 pp.

SHABALALA A (2013) Assessment of locally available reactive materials for use impermeable reactive barriers (PRBs) in remediating acid mine drainage. Water SA 39 (2) 251-256. https:// doi.org/10.4314/wsa.v39i2.8

SHABALALA AN, EKOLU SO, DIOP S and SOLOMON F (2017) Pervious concrete reactive barrier for removal of heavy metals from acid mine drainage- column study. J. Hazardous Mater. 323 641653. https://doi.org/10.1016/j.jhazmat.2016.10.027

SOLPUKER U, SHEETS J, KIM Y and SCHWARTZ FW (2014) Leaching potential of pervious concrete and immobilization of $\mathrm{Cu}$, $\mathrm{Pb}$ and $\mathrm{Zn}$ using pervious concrete. J. Contam. Hydrol. 161 35-48. https://doi.org/10.1016/j.jconhyd.2014.03.002

SUPONIK T and BLANCO M (2014) Removal of heavy metals from groundwater affected by acid mine drainage. Physicochem. Probl. MI 50 (1) 359-372. http://dx.doi.org/10.5277/ppmp140130

TESTA SM, LEHR JH and JAMES A (2013) Acid Mine Drainage, Rock Drainage, and Acid Sulphate Soils: Causes, Assessment, Prediction, Prevention, and Remediation ( $1^{\text {st }}$ edn) John Wiley and Sons Ltd, New Jersey. 520 pp.

THIRUVENKATACHARI R, VIGNESWARAN S and NAIDU R (2008) Review: Permeable reactive barrier for groundwater remediation. J. Ind. Eng. Chem. 14 (2) 145-156. https://doi. org/10.1016/j.jiec.2007.10.001

THOMAS JJ, JENNINGS HM and ALLEN AJ (1998) The surface area of cement paste as measured by neutron scattering-evidence of two C-S-H morphologies. Cement Concrete Res. 28 (6) 897-905.

USEPA (United States Environmental Protection Agency) (1986) The Environment (Protection) Act, Rev. 1998, General standards for discharge of environmental pollutants Part-A: effluents, Schedule VI, Gazette of India, S.O. 844(E), Revised G.S.R. 7. URL: http:// www.envfor.nic.in/legis/env/env4.html (Accessed 5 August 2017).

VADAPALLI VRK, KLINK MJ, ETCHEBERS O, PETRIK LF, GITARI W, WHITE RA, KEY D and IWUOHA E (2008) Neutralization of acid mine drainage using fly ash, and strength development of the resulting solid residues. S. Afr. J. Sci. 104 (7-8) 317-322.

WANG Y, PLEASANT S, JAIN P, POWELL J and TOWNSEND T (2016) Calcium carbonate-based permeable reactive barriers for iron and manganese groundwater remediation at landfills. Waste Manage. 53 128-135. https://doi.org/10.1016/j.wasman.2016.02.018

WHO (World Health Organization) (2003) Chromium in drinkingwater. WHO/SDE/WSH/03.04/04. World Health Organization (WHO), Geneva. URL: https://www.who.int/water_sanitation_ health/dwq/chemicals/chromium.pdf (Accessed 23 February 2019)

YANG J and JIANG G (2003) Experimental study on properties of pervious concrete pavement materials. Cement Concrete Res. 33 (3) 381-386. https://doi.org/10.1016/s0008-8846(02)00966-3

YOUNGER PL (2004) The mine water pollution threat to water resources and its remediation in practice. Hydrogeochemical Engineering Research and Outreach (HERO), School of Civil Engineering and Geosciences. University of Newcastle, Newcastle. 48 pp.

ZHITKOVICH A (2011) Chromium in drinking water: sources, metabolism, and cancer risks. Chem. Res. Toxicol. 24 (10) 16171629. https://doi.org/10.1021/tx200251t 